\title{
The Bodleian and Its Founder
}

In this brief paper Bodley's present librarian brings to date the account of the storied Oxford institution over which he has presided for many years.

$\mathrm{F}$ OUR HUNDRED YEARS AGO- on March 2, 1545, according to the Gregorian calendar-Thomas Bodley was born in the city of Exeter, England. Like Raleigh and Drake and other great figures of Elizabethan England he was a Devon man. His father was a zealous Protestant who found refuge from religious persecution at Geneva, and here he received his early education. But the accession of Queen Elizabeth allowed his return to England and his entry as a student into the University of Oxford, the place with which his name will be forever associated.

After taking his degree, he was elected a fellow of Merton College, gave lectures both in Greek and in natural philosophy (the sixteenth-century equivalent of science), and acted as deputy for the public orator of the university. When he was past thirty years he decided to enter the diplomatic service and, with this in view, traveled for some years in Italy, France, and Germany in order to acquire a knowledge of modern languages.

At the age of forty he began to be employed on missions to foreign courts, and in 1588 - the year of the Spanish Armadahe was sent to The Hague as English Minister Plenipotentiary to the Netherlands, which had recently revolted from Spain. During the five years of his continuous residence at The Hague-a period of constant warfare between the Spaniards and the Dutch-he was a principal member of the Council of State of the Dutch Republic, taking part in all its deliberations. On two subsequent occasions he was sent back to The Hague on special missions.

His political capacity was such that he was twice pressed to accept the office of Secretary of State in the English government. Nevertheless he had no liking for party politics. His tastes were those of a scholar, and so, at the age of fifty-three, as he tells us in his autobiography, "I resolved to possess my soul in peace all the residue of my days, to take my farewell of state employments, and to retire from the court." His decision to direct his talents to another sphere was destined to win for his name an undying renown.

From the beginning of the fourteenth century the University of Oxford had housed its library in a room adjoining the university church. Large gifts from an English prince, Humfrey, Duke of Gloucester, brought about the erection of a new library building in the second half of the fifteenth century. It formed an upper story to the divinity school. It remains today the main Bodleian reading room and is still known as Duke Humfrey's Library.

But its contents had been dispersed at the English Reformation, and all that was left was a great desolate room, stripped of both books and bookcases. Surveying it, Bodley came to the conclusion that "I could not busy myself to better purpose than by reducing that place, which then lay ruined and waste, to the public use of the students." 
Consequently, in 1598 he made an offer to the university that he would restore the room at his own cost to its former use, refurnish it, procure books for it, and provide an endowment. He had means of his own to carry out the work and what he called a "great store of honorable friends" to assist him in the undertaking.

His offer was accepted with the gratitude which its munificence deserved. For four years the work proceeded. The stillexisting bookcases were installed, the beautiful painted roof which still adorns the room was erected, and some two thousand printed books and manuscripts were collected to form the nucleus of the library. It was formally opened on Nov. 8, I602.

\section{Library's Early Years}

Sir Thomas Bodley survived the opening of his library by ten years. His correspondence with his first librarian is still extant and reveals the interest and zeal with which he attended to every detail of library management. The greatest service which he rendered to the library was the making of an agreement with the Stationers' Company (the trade union of English publishers) whereby the company undertook to present a copy of every book which it printed. This privilege has been confirmed by successive copyright acts and is now shared by the British Museum, the National Library of Scotland, and the libraries of Cambridge and Trinity College, Dublin.

Bodley also extended the library building by the addition of an eastern wing and left money for the erection of a top story to the university schools which were built, shortly after his death, round a quadrangle adjoining the original library. Dying on Jan. $28, \mathrm{I}_{1} \mathrm{I}_{3}$, he was buried in the chapel of his college of Merton, where a monument by a well-known English sculptor, Nicholas Stone, records his memory.
The Bodleian Library, as it is called in memory of its founder, is the largest of British university libraries. All members of the University of Oxford have the privilege of reading in it. Down to the middle of the nineteenth century its readers were in practice limited to university graduates and other learned men. Undergraduate students did their reading in the libraries attached to their respective colleges.

But in I $86 \mathrm{I}$ a neighboring library building, the Radcliffe Camera, was taken over and converted into a reading room for undergraduates. The camera is a circular building in Palladian style, completed in I 747 by the architect James Gibbs. Its lofty dome forms one of the most conspicuous features of the center of Oxford. The accommodation which it gives has been more than doubled in recent years, partly as the result of fitting up its lower story as an additional reading room.

\section{Science Library}

Further library provision was made in 1927, when a library of scientific books, named the Radcliffe Science Library, was handed over to the university. This building, to which a large new wing was added seven years later, lies within the area occupied by the university's science departments, and its use is supplemented by the specialist libraries belonging to those departments.

The Bodleian is more, however, than a university library. Ever since its foundation by Sir Thomas Bodley it has been a public library, and in consequence it ranks as one of the oldest public libraries existing in Europe. Scholars from all parts of the world are admitted to read within its walls, on production of evidence that they are engaged in the pursuit of learning.

Until the British Museum was established in the middle of the eighteenth century, the Bodleian filled the role of a national library, for no other library in 
Britain was so rich in collections of manuscripts and of early printed books. The bulk of its collections are naturally of English origin. Nowhere else will one find so many manuscripts intact in their medieval English bindings. The most important manuscript material for the history of England in the seventeenth century is here. The Malone collection is the finest of its kind for Shakespeare and early English drama.

But equally important collections have come to Bodley from abroad. Among them are the Greek manuscripts of the Genoese collector Barocci; a large library of manuscripts, mainly of Italian origin, formed by the Venetian Jesuit Canonici; the libraries of classical literature formed by the Dutch scholars Meerman and Dorville; and besides these one may mention a collection of Icelandic literature and a series of Polish books-some of which are of extreme rarity -purchased in 1850 .

\section{Oriental Collections}

The Bodleian is equally famous for its Oriental collections. It is particularly rich in Arabic manuscripts; possesses a remarkably fine series of Persian illuminated manuscripts; owns the unrivaled library of Hebraica formed by Rabbi Oppenheimer, of Prague; has a very large number of Sanskrit manuscripts; and has formed a good collection of Chinese printed books.

The Bodleian is the second largest library in Britain and the British dominions. Only the British Museum surpasses it in its contents. The number of volumes on its shelves exceeds a million and a half. It is not surprising that the finding of space for its accessions has in the past been a constant, difficult problem.

In 1933 the University of Oxford started upon a scheme of library extension then estimated to cost nearly a million pounds sterling, of which sum the Rockefeller
Foundation most generously offered to contribute three-fifths. The remainder of the sum needed was found by the university from its own resources and from the subscriptions of its members and other benefactors.

\section{The New Library}

The main feature in the program of extension was the erection of a large annex, named the New Library, the core of which is a vast bookstack capable of containing four million books. This new building is the work of the foremost of living English architects, Sir Giles Gilbert Scott, and is in neoclassical style. It was commenced in 1937 and completed in 1940. All library books, other than those kept on the open shelves of the reading rooms, have been transferred to it.

After the present war is ended qualified readers will have limited access to its shelves - a radical departure from the current practice of English libraries, which does not allow readers access to the stack but requires them to order books for use in reading rooms. The stack is heated by the method of thermal storage-that is to say, by water circulated from cylinders heated by electric power-and is air conditioned. The building, though stone-faced, is otherwise entirely constructed of concrete and steel, all shelving and fittings being of steel and consequently fire-resistant.

The greater part of the stack is below ground level, and the whole is lit by electric light, though the top stories which rise above the surrounding building, have natural lighting. Small carrels, or studies for readers, have been provided on these upper floors. The outer rooms of the building, which surround the stack, have been planned as exhibition rooms; working rooms and rest rooms, with a canteen for the staff; a bindery; photographic rooms, including a room for reading microphotographic films; 
seminars and rooms for cooperative research; and a large reading room for economics and social science.

But no library use has yet been made of them, for, as soon as they were completed, they were taken over for war purposes. Among the uses to which they have been put one may mention blood transfusion.

No further building has been possible since the autumn of 1940. The war has halted the library extension scheme, which would otherwise have been completed in 1942. When building again becomes feasible, the old university schools surrounding the Bodleian quadrangle, which have now been cleared of books formerly stored in them, will be converted into a range of reading rooms for the humanities and legal studies, containing on open shelves upwards of one hundred thousand select works of reference.

But, although war has stopped further library development, service to readers has hardly been reduced; in fact, in the science library, where much research is carried out for the government, it has been increased. This is despite the fact that, out of the hundred members of the library staff, almost all those of military age have left to join the fighting forces or to take up other forms of national service, their places being taken for the most part by women and by boys and girls below the age of eighteen.

Sir Thomas Bodley's original endowment of $£_{130}(\$ 520)$ a year has been increased to a total income of about $£ 35,000$ $(\$ 140,000)$. Of this sum £II,000 $(\$ 44,000)$ is derived from a government grant made to the university; about $£ 8,500$ $(\$ 34,000)$ is contributed by the university out of its own resources or by colleges; and the library's own endowment is a little over $£ 7,500(\$ 30,000)$. His library staff of two has increased to a hundred, and his library of two thousand books will soon number two million.
THE FOLLOWING announcement comes from the International Relations Office of the American Library Association:

The Washington office of the American Library Association's International Relations Board has received from the Division of Cultural Cooperation of the Department of State a list of sixty-eight Swiss institutions receiving periodicals on exchange from the United States, some six hundred in number.

The first title listed is Abridged Scientific Publications, Research Laboratory, Eastman Kodak Company, Rochester, N.Y. The last is Zoological Scientific Contributions of the New York Zoological Society.

The record comes from M. Marcel Godet, director of the Swiss National Library, through Leland Harrison, American minister to Switzerland.

Switzerland hopes that exchange relations may be resumed as soon as postal relations become normal once more.

This note is sent to let the issuing offices in this country know of this hope and to assure retention of back numbers and provision of future current issues to complete Swiss files when conditions permit.

The university library at Basle and the central library at Zurich were unable to list their exchanges. So too the library of the League of Nations at Geneva made no report.

The American Library Association has received from the Faculty of Medicine at Montevideo a collection of recent Uruguayan medical books and periodicals, comprising some 140 pieces, in exchange for books sent to the faculty as part of the Books for Latin America program. The director of the library of the faculty, Dr. Alejandro F. Sarachaga, is anxious to establish exchanges of the Anales de la Facultad de Medicina with medical publications of the United States and will welcome correspondence to that effect. 